\title{
Evidence, Perceptions, and Trade-offs Associated with Invasive Alien Plant Control in the Table Mountain National Park, South Africa
}

\author{
Brian W. van Wilgen $^{1,2}$
}

\begin{abstract}
The Table Mountain National Park is a $265 \mathrm{~km}^{2}$ protected area embedded within a city of 3.5 million people. The park contains an extremely diverse flora with many endemic species, and has been granted World Heritage Site status in recognition of this unique biodiversity. Invasive alien plants are arguably the most significant threat to the conservation of this biodiversity, and the past decade has seen the implementation of aggressive programs aimed at the removal of invasions by these plants. These invasive alien plants include several species of trees, notably pines (Pinus species) and eucalypts (Eucalyptus species), which historically have been grown in plantations, and which are utilized for recreation by the city's residents. In addition, many citizens regard the trees as attractive and ecologically beneficial, and for these reasons the alien plant control programs have been controversial. I briefly outline the legal obligations to deal with invasive alien plants, the history of control operations and the scientific rationale for their implementation, and the concerns that have been raised about the operations. Evidence in support of control includes the aggressive invasive nature of many species, and the fact that they displace native biodiversity (often irreversibly) and have negative impacts on hydrology, fire intensity, and soil stability. Those against control cite aesthetic concerns, the value of pine plantations for recreation, the (perceived) unattractive nature of the treeless natural vegetation, and the (incorrect) belief that trees bring additional rainfall. The debate has been conducted through the press, and examples of perceptions and official responses are given. Despite opposition, the policy promoting alien plant removal has remained in place, and considerable progress has been made towards clearing pine plantations and invasive populations. This conservation success story owes much to political support, arising largely from job creation, and a strong body of scientific evidence that could be cited in support of the program.
\end{abstract}

Key Words: biodiversity conservation; ecosystem management; forestry; fynbos; pines

\section{INTRODUCTION}

Invasive alien species affect agriculture, forestry, and human health, and are also widely recognized as the second largest global threat (after direct habitat destruction) to the conservation of biodiversity (Wilcove et al. 1998, Walker and Steffen 1999). These species can dominate a wide range of habitats, where they alter the functioning, structure, and composition of these habitats, often with serious consequences (Perrings et al. 2010). Almost all of the scientific literature that deals with invasive alien species stresses their serious negative impacts, and urges policy-makers and land managers to take appropriate steps to prevent or contain these invasions. However, some invasive alien species also have value. For example, several species of commercially important trees that are used in plantation forestry are also invasive (Richardson 1997, De Wit et al. 2001). Other species may have particular appeal as ornamental plants. Conflicts often arise between people who hold different points of view or who subscribe to different value systems, and these conflicts are often heightened because of partial understanding, or ignorance, regarding the merits of particular viewpoints. Attitudes can also shift over time as new knowledge and understanding arises, and as value systems change. South Africa has a long history of management of invasive alien plants (Richardson and van Wilgen 2004, Zimmermann et al. 2004, van Wilgen 2009), and there is much to be learned about perceptions and trade-offs from the implementation of these projects.

In the Cape Floristic Region (see Cowling et al. 2003) of South Africa, invasive alien plants, especially trees and shrubs, are a significant threat to the conservation of biodiversity and other ecosystem services (van Wilgen et al. 2008). In this region, as elsewhere in the world, attitudes towards alien trees have shifted significantly during the past century. From being regarded almost universally as assets with commercial, aesthetic, and other values, they are now regarded by many as a threat to natural ecosystems and the benefits that these ecosystems deliver. Despite the shift, there are significant sections of society that hold one or the other view, and this has led to a degree of conflict regarding the management of these species. The Table Mountain National Park (TMNP), a significant protected area within the Cape Floristic Region, is surrounded by a densely populated city, with the result that alien plant management often comes under close scrutiny and criticism. In this paper, I describe the nature of this tension, and the manner in which it has been managed over the past decade, and I highlight the probable reasons for the ongoing success of the invasive alien plant clearing program. 


\section{POLICY BACKGROUND}

Alien species are defined as those species whose presence in a region is attributable to human actions that enabled them to cross biogeographical barriers and arrive in the new environment. Invasive alien species are a subset of alien species that can sustain self-replacing populations over several life cycles, often in large numbers and at considerable distances from the site of introduction (Richardson et al. 2011). In South Africa, and particularly in the Western Cape Province, the problem of invasive alien plants has long been recognized (Wicht 1945, Alien Vegetation Committee 1959, Stirton 1978). Biological invasions were identified in 1982 as a problem of global concern by the Scientific Committee on Problems of the Environment (SCOPE). SCOPE initiated a large international project to review and improve understanding of biological invasions and their implications, which lead to the publication of the South African component of this work in 1986 (Macdonald et al. 1986). This synthesis volume set out the current understanding and provided the necessary scientific backing for the development of policies that were to follow.

The first policy instrument that directly addressed the management of invasive alien plants in South Africa came about in the form of regulations under the Conservation of Agricultural Resources Act ([CARA] Act 43 of 1983, as amended in 2001). These regulations declared 57 alien plant species as "noxious weeds" (Government Notice No. R1048 of 25 May 1984, as amended by Government Notice No. 2687 of 6 December 1985). Landowners who had declared weeds on their land were required by law to take adequate steps to control them, and to prevent their spread. South Africa became a Party to the Convention on Biodiversity (CBD) in November 1995, following the establishment of the country's first democratically elected government in 1994. Article 8(h) of this convention calls on Parties to "prevent the introduction of, control or eradicate those alien species, which threaten ecosystems, habitats or species". In 2001, the list of noxious weeds was expanded to include 198 species (Government Gazette, Vol. 429, No. 22166 of 30 March 2001). The revised approach classified weeds into three categories: (1) weeds of no value; (2) recognized weeds that also have commercial value; and (3) recognized weeds that have ornamental but no commercial value. For weeds in the first category, control is required, and trade is banned. Landowners require permits to grow weeds in the second category, and are required to take steps to limit their spread; trade in these species and their products is permitted. Weeds in the third category (created to accommodate popular ornamental plants) are also subject to permits that require steps to limit their spread, but further plantings, and the sale of plants and their products, is prohibited. Six tree species in the genus Pinus, and seven in the genus Eucalyptus, were added to the list in the second category. The more recent National Environment
Management: Biodiversity Act ([NEMBA] Act 10 of 2004) has yet to finalize its regulations but plans to introduce similar categories that will complement those provided for by CARA. The major difference is that invasive alien plants in category 1 will be split into subcategories that recognize that some species with a very high invasive potential will need to be placed under a government sponsored management program in which landowners will be assisted with their legal obligations to control the spread of particularly aggressive invasive species. Both the CARA and the NEMBA legislative instruments give substance to South Africa's obligations in terms of the CBD, and provide the background against which the management of invasive alien plants must take place in the TMNP.

Invasive alien plant control programs in South Africa are led by the Working for Water programme, a government sponsored poverty relief initiative that creates employment opportunities for the rural poor, while simultaneously addressing the problem of invasive alien plants (van Wilgen et al. 1998, 2011). The programme was established in 1995 under a unique set of circumstances that made it possible to secure funding and launch the programme (van Wilgen et al. 2011). These circumstances included a desire on the part of the newly elected democratic government to change many things following three centuries of discriminatory rule, with a focus on improving the lot of the rural poor. Against this background a group of ecologists presented the viewpoint to the government that invasive alien plants were a large and growing national problem, presenting a serious threat to water resources, and that by actively addressing these problems, poor people in underdeveloped rural areas would be able to secure employment. The Working for Water programme was established as a result. Continued support for Working for Water was secured through a demonstrated ability to invest the allocated funds and create employment at a time when most government departments found this difficult due to a lack of capacity (van Wilgen et al. 2011).

\section{THE TABLE MOUNTAIN NATIONAL PARK}

\section{Salient features}

The Table Mountain National Park, established in 1998, is a rugged $265 \mathrm{~km}^{2}$ area on the Cape Peninsula (centered at $34^{\circ} 09^{\prime}$ S, $\left.18^{\circ} 23^{\prime} \mathrm{E}\right)$, surrounded by the city of Cape Town, South Africa. In 2004, the park obtained World Heritage Site status in line with its global importance as a hotspot of biodiversity for higher plants and invertebrates (Cowling et al. 1996). The dominant vegetation of the park is fynbos (Mediterraneanclimate shrubland vegetation typical of the Cape Floristic Region), and it is home to 2285 plant species, of which 90 are endemic. Prior to establishment as a national park, the area was managed by 14 separate public bodies; as a result, the earlier conservation management of the area was uncoordinated and fragmented (van Wilgen 1996). Prior to 
1998, the area's unique biodiversity faced numerous threats, including invasion by a range of alien plant species (Richardson et al. 1996). One of the major aims of consolidating land parcels into a single conservation area was to promote a coordinated approach to invasive alien plant management (van Wilgen 1996).

\section{Management vision}

The managers of the TMNP have set out a vision that focuses on maintaining and restoring natural vegetation as its primary objective. South African National Parks has an overriding mandate to conserve South Africa's biodiversity, landscapes, and associated heritage assets on the land that they control (SANParks 2008b). This is interpreted in the TMNP management plan (SANParks 2008a) as protecting the natural and unique vegetation of the park. The core values, as set out in the plan, include the need to maintain the unique natural ecosystems for the enjoyment, appreciation, and benefit of people, in such a way that future options are not compromised. The restoration of degraded habitats, including the removal or control of "all alien flora", is seen as key to maintaining biodiversity within the TMNP. Currently, the focus is on invasive woody plants, and "secondary" nonwoody invasive plants will receive attention in the future. Where noninvasive alien plants occur within the park, especially as part of a heritage site, it is recognized that they need to be managed accordingly so that biodiversity is not compromised.

\section{INVASIVE ALIEN PLANTS IN THE TABLE MOUNTAIN NATIONAL PARK}

\section{Introduction of invasive alien plant species}

Alien plants, particularly trees and shrubs, were introduced to the TMNP and elsewhere in the Cape Floristic Region for a range of reasons, the most common of which were to provide timber (species in the genera Pinus and Eucalyptus), and to stabilize shifting sand dunes (species in the genera Acacia and Leptospermum). During the late $19^{\text {th }}$ and early $20^{\text {th }}$ centuries, these species were widely planted (Shaughnessy 1986). Some species were introduced as far back as the late 1600s (Poynton 1977), but the establishment of large timber plantations of pines and eucalypts along the lower slopes of what is now the TMNP took place only between 1885 and 1904 (Poynton 1977, 1979). These widespread plantings provided the source of seeds that later invaded the surrounding natural vegetation.

\section{Processes of invasion}

In the TMNP, invasive alien trees fall into two broad groups. The first includes species of Pinus and Hakea, which are serotinous and carry large numbers of seeds in cones or follicles in the canopy of the trees. These plants are killed by fire, following which winged seeds spread over large areas where they establish in the post-fire environment. The second group includes species in the genus Acacia, which shed copious numbers of hard-coated seeds, which build up in the soil, and are stimulated to germinate by fires, or during soil movement, for example, down rivers. Unlike pines and hakeas, many of these species also have the ability to sprout when felled, which complicates their management. The processes whereby species of Leptospermum and Eucalyptus invade ecosystems are less well studied. Pines and hakeas can invade all areas, mainly after fires, while Acacia species (and, to a lesser extent, some Eucalyptus species), invade riparian zones.

\section{Current levels of occupation}

It is necessary to distinguish between invasive alien plants where they have invaded the natural fynbos vegetation, and plantations, where alien tree species were originally established for timber production, and are now utilized for recreation purposes as well. Formal plantations occupy less than 1000 ha in the TMNP, and most have been earmarked for clearing and rehabilitation to natural vegetation. Following the establishment of timber plantations, some species (notably pines, Pinus species) spread beyond the borders of formal plantations and invaded the surrounding fynbos shrublands. The most important invasive species in the TMNP include trees and shrubs from the genera Acacia (three species), Pinus (three species), Eucalyptus (two species), Hakea (two species), and Leptospermum (one species) (Richardson et al. 1996). Collectively, these species covered 6513 ha $(24 \%$ of the TMNP) in 1996, and they have the potential to cover most $(98.5 \%)$ of the remaining natural vegetation if left to spread unchecked (Richardson et al. 1996).

\section{Management responses}

The threat posed by invasive alien plants was recognized by botanists as early as 1888 (Stirton 1978). Other than some awareness-raising publications that appeared in the latter half of the $20^{\text {th }}$ century (Alien Vegetation Committee 1959, Stirton 1978), little was done on the Cape Peninsula to effectively stem the spread of invasive alien plants until the 1980s. Although few campaigns were adequately documented, evidence shows that poor understanding of the ecology of invasive species, as well as a lack of follow-through when clearing was done, led to much wasted effort and money. For example, 47 years of control attempts on the southern part of what is now the TMNP were "almost totally ineffective for the first 35 years" (Macdonald et al. 1989). The then Department of Forestry ran an effective alien plant control program in the Western Cape between the late 1970s and early 1980s (Fenn 1980), but this had little impact on the area that is now the TMNP. Following the creation of the TMNP, invasive alien plant control plans were drawn up, and control operations became coordinated.

The TMNP's management plan (SANParks 2008a) calls for the eradication (sic) of invasive alien woody plants, in line with national legislation and the primary mandate to conserve natural biodiversity and landscapes. Priorities for the control are reviewed annually, and invasive plants have been felled 
on $85 \%$ of the TMNP since the program began in 1998. The control of invasive alien plants in areas of natural vegetation tends not to be as controversial as the clearfelling of plantations, although it is often the same species of trees that are involved. The TMNP aims to increase the area of initial clearing of invasive plants from fynbos by $5 \%$ per annum, and to conduct follow-up treatments on all areas at least once every two years. Funding (9 million rand, approximately US $\$ 1.3$ million) is sourced through Working for Water, a governmentsponsored program (see van Wilgen et al. 2011) to employ poor people from rural areas in control operations. The management plan estimates that follow-up programs will be required for at least the next 80 years in order to reduce persistent soil-stored seed banks to acceptable levels.

The TMNP's policy regarding plantations is to remove all pine plantations over the next decade, and to rehabilitate the sites to natural vegetation. Several of these pine plantations were burned in wildfires in January 2000, and TMNP managers used this as an opportunity to clearfell the affected plantations, including unburned portions of the plantations, which led in turn to public criticism. The policy regarding plantations of Eucalyptus trees differs in that some, but not all, plantations will be removed. There are two reasons for this. First, eucalypts are not as aggressively invasive as pines (Forsyth et al. 2004), although they do spread down drainage lines. Secondly, some plantations of large, 100-year-old eucalypts are regarded as both historically significant and aesthetically attractive, and will be retained as recreational areas.

\section{OPPOSING VIEWS OF ALIEN PLANT CONTROL}

\section{The case for clearing invasive plants}

Research over the past two decades has built a relatively robust body of evidence that quantifies the impacts of invasive alien plants on fynbos ecosystems, as well as the benefits of control (van Wilgen et al. 2001, van Wilgen 2004, De Lange and van Wilgen 2010). For most of the $20^{\text {th }}$ century, invasive alien plant control programs were carried out almost entirely for reasons of biodiversity conservation (Alien Vegetation Committee 1959, Stirton 1978). It had also long been recognized that, in addition to negative impacts on indigenous vegetation, invasive alien trees could reduce streamflow in much the same way as commercial forestry did (Kruger 1977a, Versfeld and van Wilgen 1986, van Wilgen et al. 1992, Cowling et al. 2009). It was not until the late 1990s, however, that researchers attempted to accurately quantify these potential losses of water resources. Various studies carried out in the 1990s demonstrated that:

- invasions of catchment areas by alien trees and shrubs, if left unchecked, would decrease streamflow by the equivalent of $30 \%$ of the annual water supply to the city of Cape Town (Le Maitre et al. 1996);

- despite higher catchment management costs overall when alien plant management projects were implemented, the costs per unit of water "produced" would be lower when such projects were in place (van Wilgen et al. 1996);

- investing in the management of invasive alien species in the catchments of existing dams would deliver water at a much lower cost than would be the case if a new dam was built (van Wilgen et al. 1997); and

- an early investment in alien plant control, rather than postponing the control to a later date, would deliver more attractive returns on investment (van Wilgen et al. 1997).

Although this understanding is fairly robust, there are also important gaps. The estimates of plant water use that are used to illustrate water-related benefits of the control of invasive alien plants are based on relatively few species (mainly those with commercial forestry value). In addition, significant challenges exist when planners and managers attempt to scale up by using understanding gained at relatively small spatial and temporal scales to predict and plan at larger scales (Görgens and van Wilgen 2004). These gaps in understanding add a level of uncertainty to predictions of impacts on, or of benefits to, water resources.

Understanding of the impacts of invasive trees and shrubs on the biodiversity of fynbos vegetation has also improved, although the topic has been remarkably poorly researched. In a review of the impacts of invasive alien plants on ecosystem functioning and the delivery of ecosystem services, Richardson and van Wilgen (2004) concluded that these aspects had been poorly studied, with the notable exception of impacts on water resources. These authors identified a predictive understanding of the rates of spread of invasive alien plants, and the development of achievable goals for ecosystem repair after clearing as key priorities for future research.

Invasions by alien plants are also understood to increase biomass (fuel loads) and thus fire intensity in natural vegetation invaded by trees and shrubs, which in turn leads to soil damage and excessive erosion. Typical fuel loads in shrublands are around 3-5 tonnes per hectare (van Wilgen and van Hensbergen 1992), while invaded sites have up to eight times more fuel (10-25 tonnes per hectare) (van Wilgen and Richardson 1985). This increase in biomass comes about when the fynbos shrublands are invaded by tree and shrub species with relatively rapid growth rates and larger size (Versfeld and van Wilgen 1986). While fynbos ecosystems are normally quite resilient to regular burning, these increased fuel loads lead to higher intensity fires and a range of detrimental effects. Physical damage to the soil can occur, resulting in increased erosion after fire. For example, 6 tonnes of soil per hectare was lost following fires in pine stands compared to 0.1 tonnes per hectare following fire in adjacent fynbos in the Western Cape (Scott et al. 1998). The viability of indigenous seeds can be reduced, causing poor regeneration from soil-stored seed banks (Cocks and Stock 1997, Jeffrey et al. 1988, Holmes and 
Richardson 1999). Intense fires in invaded fynbos vegetation will therefore favor recruitment for some alien species by promoting their germination over that of indigenous species. In addition to direct effects, invasion by alien plants compounds fire management problems-densely invaded areas are impenetrable, and restricted access makes fires more difficult to contain.

Finally, there is evidence from the Cape Peninsula (and elsewhere in fynbos ecosystems) that ecosystem diversity can be restored after invasive alien plant control operations, especially in areas that were not too heavily invaded or have not been invaded for so long that the soil-stored seed banks have become substantially depleted (Holmes and Richardson 1999). Managers have typically relied largely on the unaided recovery of native species from residual individuals or seed banks to drive restoration (Vosse et al. 2008), but areas that have been densely invaded for long periods could require further interventions in the form of reintroductions of certain major plant guilds (groups of plants with similar response strategies for dealing with disturbance) to ensure that the original guild structure of the vegetation could be restored (Holmes and Richardson 1999). There is further strong support for the removal of alien pines on the Cape Peninsula based on the recovery of invertebrate diversity following clearing (Pryke and Samways 2009). In addition, Samways et al. (2005) reported that extremely rare, endemic dragonfly species on the verge of extinction recovered rapidly following removal of dense stands of invasive alien trees.

\section{Concerns regarding the negative impacts of control}

Over the past decade, a number of issues and concerns have been raised relating to (1) invasive alien plant control projects, and (2) the removal of plantations of invasive alien species. To identify the range of concerns, I surveyed the three main local newspapers (Cape Argus, Cape Times, and Die Burger) for articles relating to these issues between 2000 and 2010 . For the purposes of discussion, these can be grouped as follows: (1) impacts on soil and water resources; (2) impacts on biodiversity and ecosystem health; (3) impacts on aesthetics and recreational opportunities; (4) impacts on climate change; (5) conflicts between the concept of alien plant control and people's value systems (ethical values); and (6) potentially negative impacts on economic activities (economic value). Each is discussed briefly below, and Table 1 provides further details and references.

There is a strong belief among many people that tree cover is correlated with rainfall, and that planting trees will increase rainfall, although strong evidence in support of this popular belief does not exist (Calder 1999). This belief was one of the reasons for the widespread historic planting of alien trees in the Cape Floral Region. The scarcity of natural forests in the fynbos has intrigued scientists for a long time (Moll et al. 1980). Modern understanding suggests that natural forest patches in fynbos are restricted by recurring natural fires, and much of the area would develop into forest in the absence of fire (Manders et al. 1992, Geldenhuys 1994). In the Cape Peninsula, rains are carried in over the ocean by frontal systems, and local rainfall remains unaffected by the establishment of pine plantations (Wicht et al. 1969). The idea that forest cover in general is the best way of protecting the soil and ensuring a sustained water supply from catchments is also widespread but not valid in cases such as the establishment of plantations of alien trees (Calder 1999). Linked to these issues are concerns that felling of plantations and invasive trees will lead to excessive erosion. The evidence showing that invasive alien trees reduce streamflow has also been cited as a possible explanation for flood events in areas cleared of trees (Table 1).

In terms of concerns about biodiversity, the clearing of invasive alien plants and plantations is frequently seen as a form of habitat destruction. This is particularly so in terms of the habitat alien trees provide for animals (for example, pine trees support populations of alien grey squirrels, Scurius carolinensis), or in terms of nesting sites for birds, notably raptors, many of which have undergone range expansions in response to the increased numbers of trees (Curtis et al. 2005). In broader terms, clearing of trees and shrubs is regarded as further damage to ecosystems that are already under stress.

People mainly regard trees as aesthetically pleasing, and the establishment of trees in an environment where they were naturally rare, or were severely depleted by early colonists for timber, was the original motivation for the importation of many species. Changing views in light of new evidence regarding their negative consequences have not been universally embraced, and clearing operations have been frequently criticized as a result (Table 1). Many plantation areas are also heavily utilized by urban people for recreation (picnicking, cycling, walking), mainly because of the shade that they provide, and these citizens are highly critical of clearing.

There is increasing awareness of climate change and the potential role of trees in alleviating this problem through carbon sequestration. Generally, environmental groups and the government promote the planting of trees in line with global calls for reversing the negative effects of deforestation and the over-utilization of trees and forests. In the absence of a more detailed, area-specific understanding of the issues and trade-offs involved, the clearing of invasive trees from protected areas is seen by many as counter-intuitive to widely promoted environmental messages.

To many people, the concept of destroying trees (or other plants or animals) simply because they are alien does not make sense, and seems wrong. At worst, it is regarded as xenophobia or racism (Simberloff 2003), and the proponents of clearing programs have been labeled as "ecofascists" (Packenham 
Table 1. Major issues relating to the control of invasive alien plants, related perceptions expressed by citizens, and the position adopted by authorities responsible for invasive alien plant clearing projects in the Table Mountain National Park. Some examples of typical press articles are given.

\begin{tabular}{lll}
\hline \hline Issue & Examples of expressed public perception & $\begin{array}{l}\text { Position adopted by authorities responsible for invasive alien plant } \\
\text { clearing projects }\end{array}$ \\
\hline
\end{tabular}

Soil and water Trees bring rain, and felling them will exacerbate droughts $\quad$ There is no evidence that increased tree cover has increased rainfall resources and desiccation (Dix 2005, Wickham 2005).

(Wicht et al. 1969, Calder 1999). In contrast, long-term research indicates that invasion by alien trees and shrubs increases evapotranspiration and decreases streamflow (Görgens and van Wilgen 2004).

Felling trees will lead to excessive flooding (Ellis 2009). Flooding events that triggered the expression of this concern were caused by abnormally high rainfall ( $20 \%$ of the mean annual rainfall in 48 hours). This exceeded the previous record rainfall intensity in a 52-year record. The level of flooding was in line with the intensity of the rainfall event, and would have taken place regardless of the vegetation cover in the catchment (Hewlett and Bosch 1984), and should not be attributed to the felling of trees.

Forests, and tree cover in general, are the best way of ensuring soil conservation and of preventing erosion (Yeld 2004).

Felling trees will expose the soil and increase the risk of erosion (Ellis 2009).

Trees provide the habitat for a range of animal species, including squirrels and raptors (nesting sites), and should not be cleared.
Biodiversity and ecosystem health

There is no evidence of excessive erosion from sites with a cover of natural (nonforest) fynbos shrublands (Versfeld 1981). The naturally treeless fynbos shrublands are regarded as the best form of vegetation cover to ensure sustained yields of high-quality water (Kruger 1977b). Healthy fynbos is therefore considered sufficient to prevent erosion.

Related to this is the evidence that invasion by alien trees, or the establishment of plantations, will lead to increases in fire intensity when the areas burn. This can damage the soil and increase erosion (Lindley et al. 1988, van Wilgen and Scott 2001). As fires are inevitable in these environments (van Wilgen et al. 2010), any effort to reduce the cover of plantations, and invasions away from plantations, will reduce the risk of erosion in the longer term.

Felling of trees in plantations will expose the soil to erosion for a limited time. Experience has shown that sites where plantations have been cleared do develop a cover of vegetation within a year or two (although the full complement of species does not establish) (Holmes and Richardson 1999). The risk of erosion is therefore relatively short-lived, and needs to be assessed against the risks associated with not clearing the plantations. There is a risk that the plantations could burn in a wildfire, which will also lead to erosion (Scott et al. 1998). In addition, and more importantly, leaving the plantations in place will provide an ongoing source of seeds that will invade adjacent natural vegetation, perpetuating the problem of invasive alien plant control, and leading to more widespread risks of erosion over larger areas (van Wilgen and Scott 2001).

Some of the species that benefit from trees are themselves introduced alien species (e.g., the American grey squirrel, Scurius carolinensis), and their protection or conservation is not a priority given the focus on conserving indigenous species. Many raptors have colonized areas from which they were previously absent because of increases in tree cover. These changes would have cascading negative effects on local biota (Curtis et al. 2005). Because of the need to protect the highly diverse and often unique original biota, clearing of invasive trees should receive priority.

Scientific evidence of loss of biodiversity associated with alien plant invasion, and of the ability of ecosystems to recover after clearing does

Earth's ecosystems are self-healing, but their ability to continue to do this is compromised by widespread destruction. Clearing invasive alien plants only adds to this destruction, and is unwarranted and dangerous (Keverne 2010).

Aesthetics and recreational opportunities
Plantations of alien trees provide shade, and are often the only acceptable areas where picnics can be held on hot days (Ellis 2004). not support this view. The evidence shows that invasion can lead to reductions in species richness (Richardson et al. 1989, van den Berckt 2000, Pryke and Samways 2009), species extinctions (Raimondo et al. 2009), and trophic cascades in which reductions or extinctions in one species lead to the loss of others (Johnson 1992).

Plantations do provide this service, but the plantations provide a large seed source from which invasive populations are continually recruited. The negative impacts of invasions outweigh the benefits of shade provision, and a trade-off has to be made. 
Trees are beautiful, and they enhance the environment. In particular, plantations of century-old trees define the character of certain suburbs that border on the park (Hallauer 2000).

Climate change Trees counter climate change through carbon sequestration, and should not be felled (Yeld 2009).

Ethical values

Alien species should be protected, especially when they have been present for centuries. The control of alien species is a form of xenophobia or racism (Simberloff 2003), or ethnic cleansing (Todeschini 2000). The enthusiastic campaigns to clear alien trees and shrubs are viewed by some as being carried out by "ecofascists" (Packenham 2007).

Today's natural vegetation probably replaced some other form of vegetation in the distant past, and could thus also be classified as invasive. The invasive alien trees replacing the natural fynbos vegetation were introduced over 300 years ago, and it would be incorrect to draw an "arbitrary" line 300 years ago, and to treat species introduced then in any different way to the natural vegetation (Ellis 2004).
Economic values Alien trees are grown in plantations as a crop. Their economic value needs to be recognized. Removal of plantations will lead to loss of economic and employment opportunities (Zietsman 2000, Du Toit and Ackerman 2009).

Eucalypt trees (Eucalyptus species) are a critical resource that sustains captive bee populations. These bees are in turn critical pollinators of deciduous fruit trees, a major agricultural activity in the region. Reductions in eucalypt tree populations will have serious negative impacts on the beekeeping and deciduous fruit industries (Allsopp and Cherry 2004).
Plantations of noninvasive species (for example, eucalypts) will be retained in certain areas, but invasive species should be cleared for the same reasons outlined under "recreation and shade" above.

The advantages of carbon sequestration need to be assessed against the negative consequences of both plantations and invasive trees. The gains in carbon sequestration from alien plant invasions and from tree plantations on the Cape Peninsula will be very small. For example, the carbon offset of all plantation forestry in South Africa is only $3 \%$ of the country's carbon emissions (DEAT 2009). Losses of water resources and biodiversity are a far greater cause for concern, and models suggest that climate feedbacks associated with carbon sequestration are unlikely to offset water losses, and could even exacerbate them (Jackson et al. 2005). The motivation put forward by conservationists and ecologists is not xenophobia or racism, but rather a desire to prevent environmental or ecological harm through the removal of a significant threat (Simberloff 2003).

South African National Parks (SANParks) have a primary mandate to conserve, on the land that they manage, South Africa's biodiversity, landscapes, and associated heritage assets (SANParks 2008b). This is interpreted as protecting the natural fynbos vegetation, which evolved in situ over millions of years, from invasive species that are relatively recent introductions, and which threaten to overrun the fynbos (Richardson et al. 1996). A further responsibility to conserve the original vegetation is placed on SANParks through the declaration of the Table Mountain National Park as a World Heritage Site in recognition of the global significance of its unique biodiversity (http://whc.unesco.org/en/list/1007/ ).

Trade-offs have to be made. Where the economic value of forestry is outweighed by negative impacts (De Wit et al. 2001), a solid case can be made for removal of plantations, as the benefits gained will more than compensate for economic sacrifices (van Wilgen and Richardson, in press).

Eucalyptus species do have negative impacts on ecosystems where they are planted (especially on water resources) (van Lill et al. 1980).

However, in contrast to the policy of removing all pine plantations, the

Table Mountain National Park will retain many eucalypt plantations for their historic and aesthetic values. The difference in approach is due to the fact that, in contrast to pines, eucalypts are not highly invasive (Forsyth et al. 2004), so their impacts can be more easily contained.
2007). Operations aimed at reversing invasions in the midst of an otherwise highly modified environment are seen as unacceptably intolerant, especially given that many people in the region have themselves descended from introduced populations.

Finally, some people depend on alien plants as a source of income and economic activity. Foremost among these is the forest industry and dependent downstream activities (sawmills and processing plants), which are under threat from the removal of plantations. Beekeepers (whose charges are dependent on flowering trees, notably Eucalyptus species), and the deciduous fruit industry that depends on bees for pollination (Allsopp and Cherry 2004), were also particularly critical of plans to clear alien trees.

\section{Debating conflicting views}

Over the past decade or more, arguments for and against the clearing of invasive alien trees in the TMNP have appeared in the press, where much of the public debate has been conducted. These issues tend to surface at irregular intervals, usually triggered by an event, for example a prescribed fire as part of a control program, the clearfelling of a plantation, or rain events followed by flooding or erosion. The issues are usually raised by one or more members of the public, and replies are typically published over the next few days. Counter-arguments come from two broad sources: (1) the authorities responsible for managing the TMNP, or their direct supporters, such as the Working for Water programme; and (2) scientists and academics, many of whom were responsible for the research that underpins the motivation for control. These responses 
usually provide facts and counter-arguments to perceptions, and they are also seen as an opportunity by responding authors to promote the goal of dealing with a significant environmental problem. Examples of typical issues raised, and typical responses, are provided in Table 1.

Some concerns can be relatively easily countered by presenting facts or scientifically accepted interpretations-for example, trees do not bring rain, or stands of invasive alien plants do not harbor high levels of indigenous biodiversity (Table 1). Other concerns are genuinely valid-for example, trees do sequester carbon, they do provide shade, and they are a source of economic benefit. These concerns are usually addressed by those defending the TMNP's policies by presenting them as trade-offs within a bigger picture, where the benefit (sometimes to a few people) can be shown to be exceeded by the negative impacts (often felt by more people). Finally, those concerns that have an aesthetic basis, or are an affront to people's value systems, are more difficult to counter effectively, although authorities have an obligation to do so by citing the background to the policies they are required to implement, as outlined in Table 1. These responses usually reflect the official viewpoint that the ecosystems of the TMNP are unique and highly diverse, that they are an asset of global importance, by virtue of which they have received World Heritage Site status, and that there is therefore a global responsibility to protect them from invasion.

\section{CONCLUSIONS}

Fifteen years ago, invasive alien plants were regarded as one of the largest threats to the integrity of ecosystems in the area that is now the TMNP (Richardson et al. 1996). The degree to which this threat has been brought under control through the systematic, long-term implementation of control programs, often in the face of ongoing criticism, is a remarkable conservation success story. This success could be attributed to a number of factors, including:

- a biodiversity-friendly policy environment that was built on global concerns about environmental degradation and loss of biodiversity, and that was embraced by South Africa's newly elected democratic government, which ratified conventions, passed laws, and provided funding to support appropriate management interventions;

- the existence of a body of scientific information resulting from decades of sustained research into the ecology, effects, and management of biological invasions, which provided a sound basis for the implementation of control projects;

- a recognition of the unique nature and global importance of the Cape flora, which built on centuries of botanical exploration and research in the Cape Floristic Region (Gelderblom et al. 2003);
- an unusual degree of engagement by local academics and researchers with policy-makers and foreign funders, with the clear intention of establishing a coordinated and strategic approach to the conservation and management of the unique biodiversity of the region (Cowling et al. 2003);

- a change in attitudes, which could have been stimulated by (1) a growing body of knowledge and understanding regarding the impacts of invasive alien plants, and the inclusion of some of this understanding into school curricula; (2) a growing middle class drawn from the ranks of people previously disadvantaged by apartheid, with associated changes in their values and concerns; and (3) a change in economic priorities from a need to supply resources (through the establishment of plantations and woodlots) to a need to preserve the unique biodiversity of the TMNP and to promote conservation and the lucrative ecotourism opportunities that arise from this;

- the opportunistic use of high-profile events to promote the goals of the alien plant control program. The best example of this is a large fire in January 2000 that was used as an opportunity to launch a large environmental program, the Ukuvuka Operation Firestop Campaign (Anonymous 2004). This campaign had the goal (among others) of clearing invasive alien shrubs and trees that altered the structure of vegetation and exacerbated the fire control problem. The fire burned for eight days, covered 8000 ha, and destroyed 14 houses. This highprofile campaign included numerous posters fixed to the city's lampposts, urging citizens to "keep pines in their place", "throttle the wattle", and "blacklist the blackwood" (Anonymous 2004). Levels of awareness concerning the issue of invasive alien plants has therefore arguably been maintained at a relatively high level in and around the city of Cape Town; and

- the fact that the Working for Water programme has created significant employment among the poor is arguably the overriding feature that has ensured continued support for one and a half decades in a democratic country where the vast majority of voters are poor. Politicians are willing to face criticism of the invasive alien plant clearing projects because of the relatively strong and largely uncontested (among leading ecologists) body of scientific evidence that points to the environmental benefits that such clearing can generate. The enthusiasm for job creation needs to be seen against the background of a large and widening gap between the rich and the poor. South Africa's Gini coefficient (a measure of the relative distribution of wealth among the population of a given region) is 0.578 , placing it among the 10 countries with the highest such coefficients worldwide. As a democracy, the major concern of the 
elected government lies with the large, relatively poor majority whose priorities relate to improvements in living conditions and reductions in crime, and whose motivation to engage in debates about the environment is understandably limited. The relatively small and wealthy minority tends to be more vocal and critical on these issues. However, the fact that invasive alien plant control projects have created employment and development opportunities, and that, by and large, they have the backing of a respected scientific community, has allowed these projects to continue despite some opposition.

Thus, despite a good deal of criticism regarding aspects of the program, invasive alien plant clearing was able to remain in place, owing much to political support and a strong body of scientific evidence that could be cited in support of the program. Changing attitudes and values among the citizens of Cape Town would also have assisted the process. Dense stands of invasive alien plants have been cleared from most of the TMNP, but reaching the goal of total removal of all aliens from within the park will require ongoing support through the remainder of the $21^{\text {st }}$ century.

Responses to this article can be read online at: http://www.ecologyandsociety.org/vol17/iss2/art23/ responses/

\section{Acknowledgments:}

This paper is a product of the Urban Ecology CityLab, which is part of the CityLab programme of the African Centre for Cities at the University of Cape Town. The African Centre for Cities' CityLab programme is funded through the Mistra Urban Futures network (which is funded by Mistra the Foundation for Strategic Environmental Research and the Swedish International Development Cooperation Agency), the Provincial Government of the Western Cape (Department of Human Settlements), and the City of Cape Town. I thank Noah Schermbrucker for locating articles in the press, and Carly Cowell and Nicola van Wilgen for information in the Table Mountain National Park management plan.

\section{LITERATURE CITED}

Alien Vegetation Committee. 1959. The green cancers in South Africa-the threat of alien vegetation to our own South African veld and forest. Citadel Press, Cape Town, South Africa.

Allsopp, M., and M. Cherry. 2004. Assessment of the economic impact on the bee and agricultural industries in the Western Cape of the clearing of certain Eucalyptus species. Agricultural Research Council, Stellenbosch, South Africa.
Anonymous. 2004. Final report: Santam/Cape Argus Ukuvuka Campaign. Ukuvuka Campaign, Cape Town, South Africa.

Calder, I. R. 1999. The blue revolution: land use and integrated water resources management. Earthscan, London, UK.

Cocks, M. P., and W. D. Stock. 1997. Heat-stimulated germination in relation to seed characteristics in fynbos legumes of the Western Cape Province, South Africa. South African Journal of Botany 63:129-132.

Cowling, R. M., I. A. W. Macdonald, and M. T. Simmons. 1996. The Cape Peninsula, South Africa: physiographical, biological and historical background to an extraordinary hotspot of biodiversity. Biodiversity and Conservation 5:527550. http://dx.doi.org/10.1007/BF00137608

Cowling, R. M., R. L. Pressey, M. Rouget, and A. T. Lombard. 2003. A conservation plan for a global biodiversity hotspotthe Cape Floristic Region, South Africa. Biological Conservation 112:191-216. http://dx.doi.org/10.1016/S0006$\underline{3207(02) 00425-1}$

Cowling, R., B. W. van Wilgen, T. Kraaij, and J. Britton. 2009. How no-man's land is becoming everyone's problem: runaway pine invasions in the Outeniqua and Tsitsikamma mountains. Veld \& Flora, September 2009:147-149. http://dx doi.org/10.1049/et:20080926

Curtis, O., G. Malan, A. Jenkins, and N. Myburgh. 2005. Multiple-brooding in birds of prey: South African black sparrowhawks Accipiter melanoleucus extend the boundaries. Ibis 147:11-16.

De Lange, W. J., and B. W. van Wilgen. 2010. An economic assessment of the contribution of weed biological control to the management of invasive alien plants and to the protection of ecosystem services in South Africa. Biological Invasions 12:4113-4124. http://dx.doi.org/10.1007/s10530-010-9811-y

Department of Environmental Affairs and Tourism (DEAT). 2009. National greenhouse gas inventory South Africa: 19902000. Department of Environmental Affairs and Tourism, Pretoria, South Africa.

De Wit, M., D. Crookes, and B. W. van Wilgen. 2001. Conflicts of interest in environmental management: estimating the costs and benefits of a tree invasion. Biological Invasions 3:167-178. http://dx.doi.org/10.1023/A:1014563702261

Dix, W. E. 2005. Letter to the editor. Cape Times, January 21, 2005.

Du Toit, B., and P. Ackerman. 2009. A case of not seeing the wood for the trees. Cape Argus, February 19, 2009. 
Ellis, G. 2004. The plague of environmental absolutism. Quest 1:41-42.

Ellis, G. 2009. Letter to the editor. Cape Times, July 16, 2009. http://dx.doi.org/10.1046/j.1365-2923.1998.00199.x

Fenn, J. A. 1980. Control of Hakea in the western Cape. Pages 167-173 in S. Neser, and A. L. P. Cairns, editors. Proceedings of the Third National Weeds Conference of South Africa. Balkema, Cape Town, South Africa.

Forsyth, G. G., D. M. Richardson, P. J. Brown, and B. W. van Wilgen. 2004. A rapid assessment of the invasive status of Eucalyptus species in two South African provinces. South African Journal of Science 100:75-77.

Geldenhuys, C. J. 1994. Bergwind fires and the location pattern of forest patches in the southern Cape landscape, South Africa. Journal of Biogeography 21:49-62. http://dx.doi.org/ $\underline{10.2307 / 2845603}$

Gelderblom, C. M., B. W. van Wilgen, J. Nel, T. Sandwith, M. Botha, and M. Hauck. 2003. Turning strategy into action: implementing a conservation plan for the Cape Floral Kingdom. Biological Conservation 112:291-297. http://dx.do i.org/10.1016/S0006-3207(02)00399-3

Görgens, A. H. M., and B. W. van Wilgen. 2004. Invasive alien plants and water resources: an assessment of current understanding, predictive ability and research challenges. South African Journal of Science 100:27-34.

Hallauer, M. 2000. Pathological pine clearance kills Silvermine picnic spot. Sunday Argus, December 31, 2000.

Hewlett, J. D., and J. M. Bosch. 1984. The dependence of stormflow on rainfall intensity and vegetal cover in South Africa. Journal of Hydrology 75:365-381. http://dx.doi.org/1 $\underline{0.1016 / 0022-1694(84) 90060-X}$

Holmes, P. M., and D. M. Richardson. 1999. Protocols for restoration based on recruitment dynamics, community structure, and ecosystem function: perspectives from South African fynbos. Restoration Ecology 7:215-230. http://dx.doi. org/10.1046/j.1526-100X.1999.72015.X

Jackson, R. B., E. G. Jobbágy, R. Avissar, S. B. Roy, D. J. Barrett, C. W. Cook, K. A. Farley, D. C. Le Maitre, B. A. McCarl, and B. C. Murray. 2005. Trading water for carbon with biological carbon sequestration. Science 310:1944-1947. http://dx.doi.org/10.1126/science.1119282

Jeffery, D. J., P. M. Holmes, and A. G. Rebelo. 1988. Effects of dry heat on seed germination in selected indigenous and alien legume species in South Africa. South African Journal of Botany 54:28-34.

Johnson, S. D. 1992. Plant-animal relationships. Pages 175205 in R. M. Cowling, editor. The ecology offynbos: nutrients, fire and diversity. Oxford University Press, Cape Town, South Africa.

Keverne, G. 2010. Destruction of aliens is misguided. The Natal Witness, November 4, 2010.

Kruger, F. J. 1977a. Invasive woody plants in Cape fynbos with special reference to the biology and control of Pinus pinaster. Pages 57-74 in Proceedings of the Second National Weeds Conference of South Africa, Stellenbosch, South Africa.

Kruger, F. J. 1977b. Ecology of Cape fynbos in relation to fire. Pages 230-244 in H. A. Mooney and C. E. Conrad, editors. Proceedings of the Symposium on the Environmental Consequences of Fire and Fuel Management in Mediterranean Ecosystems. U.S. Forest Service, General Technical Report WO-3.

Le Maitre, D. C., B. W. van Wilgen, R. A. Chapman, and D. McKelly. 1996. Invasive plants and water resources in the Western Cape Province, South Africa: modelling the consequences of a lack of management. Journal of Applied Ecology 33:161-172. http://dx.doi.org/10.2307/2405025

Lindley, A. J., J. M. Bosch, and D. B. van Wyk. 1988. Changes in water yield after fire in fynbos catchments. Water SA 14:712.

Macdonald, I. A. W., D. L. Clark, and H. C. Taylor. 1989. The history and effects of alien plant control in the Cape of Good Hope Nature Reserve, 1941-1947. South African Journal of Botany 55:56-75.

Macdonald, I. A. W., F. J. Kruger, and A. A. Ferrar. 1986. The ecology and management of biological invasions in southern Africa. Oxford University Press, Cape Town, South Africa.

Manders, P. T., D. M. Richardson, and P. H. Masson. 1992. Is fynbos a stage in succession to forest? Analysis of the perceived ecological distinction between two communities. Pages 81-107 in B. W. van Wilgen, D. M. Richardson, F. J. Kruger, and H. J. van Hensbergen, editors. Fire in South African mountain fynbos: species, community and ecosystem response in Swartboskloof. Springer Verlag, Heidelberg, Germany.

Moll, E. J., B. McKenzie, and D. McLachlan. 1980. A possible explanation for the lack of trees in the fynbos, Cape Province, South Africa. Biological Conservation 17:221-228. http://dx. doi.org/10.1016/0006-3207(80)90057-9

Packenham, T. 2007. My life in a world of trees. Sunday Times, Johannesburg, South Africa, October 7, 2007.

Perrings, C., H. A. Mooney, and M. Williamson, editors. 2010. Bioinvasions and globalization: ecology, economics, management, and policy. Oxford University Press, Oxford, UK. 
Poynton, R. J. 1977. Tree planting in southern Africa. Volume 1. The pines. Department of Forestry, Pretoria, South Africa.

Poynton, R. J. 1979. Tree planting in southern Africa. Volume 2. The eucalypts. Department of Forestry, Pretoria, South Africa.

Pryke, J. S., and M. J. Samways. 2009. Recovery of invertebrate diversity in a rehabilitated city landscape mosaic in the heart of a biodiversity hotspot. Landscape and Urban Planning 93:54-62. http://dx.doi.org/10.1016/j.landurbplan.2 $\underline{009.06 .003}$

Raimondo, D., L. von Staden, W. Foden, J. E. Victor, N. A. Helme, R. C. Turner, D. A. Kamundi, and P. A. Manyama. 2009. Red list of South African plants 2009. Strelitzia 25, South African National Biodiversity Institute, Pretoria, South Africa. http://dx.doi.org/10.4102/sajs.v107i5/6.653

Richardson, D. M. 1997. Forestry trees as invasive aliens. Conservation Biology 12:18-26.

Richardson, D. M., I. A. W. Macdonald, and G. G. Forsyth. 1989. Reductions in plant species richness under stands of alien trees and shrubs in the fynbos biome. South African Forestry Journal 149:1-8. http://dx.doi.org/10.1080/0038216 $\underline{7.1989 .9628986}$

Richardson, D. M., P. Pyšek, and J. T. Carlton. 2011. A compendium of essential concepts and terminology in invasion ecology. Pages 409-420 in D. M. Richardson, editor. Fifty years of invasion ecology: the legacy of Charles Elton. Wiley-Blackwell, Oxford, UK.

Richardson, D. M., and B. W. van Wilgen. 2004. Invasive alien plants in South Africa: How well do we understand the ecological impacts? South African Journal of Science 100:4552.

Richardson, D. M., B. W. van Wilgen, S. I. Higgins, T. H. Trinder-Smith, R. M. Cowling, and D. H. McKelly. 1996. Current and future threats to plant biodiversity on the Cape Peninsula, South Africa. Biodiversity and Conservation 5:607-647. http://dx.doi.org/10.1007/BF00137612

Samways, M. J., S. Taylor, and W. Tarboton. 2005. Extinction reprieve following alien removal. Conservation Biology 19:1329-1330. http://dx.doi.org/10.1111/j.1523-1739.2005.00176. $\underline{\mathrm{X}}$

Scott, D. F., D. B. Versfeld, and W. Lesch. 1998. Erosion and sediment yield in relation to afforestation and fire in the mountains of the Western Cape Province, South Africa. South African Geographical Journal 80:52-59. http://dx.doi.org/10 $.1080 / 03736245.1998 .9713644$

Shaughnessy, G. L. 1986. A case study of some woody plant introductions to the Cape Town area. Pages 37-46 in I. A. W. Macdonald, F. J. Kruger, and A. A. Ferrar, editors. The ecology and management of biological invasions in southern Africa. Oxford University Press, Cape Town, South Africa.

Simberloff, D. 2003. Confronting introduced species: a form of xenophobia? Biological Invasions 5:179-192.

South African National Parks (SANParks). 2008a. Table Mountain National Park: park management plan. South African National Parks, Cape Town, South Africa.

South African National Parks (SANParks). 2008b. A framework for developing and implementing management plans for South African national parks. Conservation Services Division, South African National Parks, Pretoria, South Africa.

Stirton, C. H. 1978. Plant invaders: beautiful, but dangerous. Department of Nature and Environmental Conservation, Cape Town, South Africa.

Todeschini, F. 2000. Felling of aliens is just "ethnic cleansing". Cape Times, August 15, 2000.

van den Berckt, T. 2000. The ecological effect of Acacia saligna in a sand plain fynbos ecosystem of the Western Cape, South Africa. Dissertation. University of Stellenbosch, South Africa.

van Lill, W. S., F. J. Kruger, and D. B. van Wyk. 1980. The effects of afforestation with Eucalyptus grandis Hill ex Maiden and Pinus patula Schlecth. Et Cham. on streamflow from experimental catchments at Mokubulaan, Transvaal. Journal of Hydrology 48:107-118. http://dx.doi.org/10.1016/ 0022-1694(80)90069-4

van Wilgen, B. W. 1996. Management of the natural ecosystems of the Cape Peninsula: current status and future prospects. Biodiversity and Conservation 5:671-684.

van Wilgen, B. W. 2004. Scientific challenges in the field of invasive alien plant management. South African Journal of Science 100:19-20.

van Wilgen, B. W. 2009. The evolution of fire and invasive alien plant management practices in fynbos. South African Journal of Science 105:335-342.

van Wilgen B. W., W. J. Bond, and D. M. Richardson. 1992. Ecosystem management. Pages 345-371 in R. M. Cowling, editor. The ecology of fynbos: nutrients, fire and diversity. Oxford University Press, Cape Town, South Africa. http://dx. doi.org/10.1080/21513732.2011.655100

van Wilgen, B. W., R. M. Cowling, and C. J. Burgers. 1996. Valuation of ecosystem services: a case study from the fynbos, South Africa. BioScience 46:184-189. http://dx.doi.org/10.23 $\underline{07 / 1312739}$

van Wilgen, B. W., G. G. Forsyth, H. de Klerk, S. Das, S. Khuluse, and P. Schmitz. 2010. Fire management in 
Mediterranean-climate shrublands: a case study from the Cape fynbos, South Africa. Journal of Applied Ecology 47:631-638. http://dx.doi.org/10.1111/j.1365-2664.2010.01800.x

van Wilgen, B. W., and H. J. van Hensbergen. 1992. Fuel properties of vegetation in Swartboskloof. Pages 37-53 in B. W. van Wilgen, D. M. Richardson, F. J. Kruger, and H. J. van Hensbergen, editors. Fire in South African mountain fynbos: species, community and ecosystem response in Swartboskloof. Springer Verlag, Heidelberg, Germany.

van Wilgen, B. W., A. Khan, and C. Marais. 2011. Changing perspectives on managing biological invasions: insights from South Africa and the Working for Water programme. Pages 377-393 in D. M. Richardson, editor. Fifty years of invasion ecology: The legacy of Charles Elton. Wiley-Blackwell, Oxford.

van Wilgen, B. W., P. R. Little, R. A. Chapman, A. H. M. Görgens, T. Willems, and C. Marais. 1997. The sustainable development of water resources: history, financial costs and benefits of alien plant control programmes. South African Journal of Science 93:404-411.

van Wilgen, B. W., D. C. Le Maitre, and R. M. Cowling. 1998. Ecosystem services, efficiency, sustainability and equity: South Africa's Working for Water programme. Trends in Ecology and Evolution 13:378. http://dx.doi.org/10.1016/S01 69-5347(98)01434-7

van Wilgen, B. W., B. Reyers, D. C. Le Maitre, D. M. Richardson, and L. Schonegevel. 2008. A biome-scale assessment of the impact of invasive alien plants on ecosystem services in South Africa. Journal of Environmental Management 89:336-349. http://dx.doi.org/10.1016/j.jenvma $\underline{\text { n.2007.06.015 }}$

van Wilgen, B. W., and D. M. Richardson. 1985. The effect of alien shrub invasions on vegetation structure and fire behaviour in South African fynbos shrublands: a simulation study. Journal of Applied Ecology 22:955-966. http://dx.doi. org/10.2307/2403243

van Wilgen, B. W., and D. M. Richardson. 2012. Three centuries of managing introduced conifers in South Africa: Benefits, impacts, changing perceptions and conflict resolution. Journal of Environmental Management 106:56-68. http://dx.doi.org/10.1016/j.jenvman.2012.03.052

van Wilgen, B. W., D. M. Richardson, D. C. Le Maitre, C. Marais, and D. Magadlela. 2001. The economic consequences of alien plant invasions: examples of impacts and approaches to sustainable management in South Africa. Environment, Development and Sustainability 3:145-168.

van Wilgen, B. W. and D. F. Scott. 2001. Managing fires on the Cape Peninsula: dealing with the inevitable. Journal of Mediterranean Ecology 2:197-208.
Versfeld, D. B. 1981. Overland flow on small plots at the Jonkershoek Forestry Research Station. South African Forestry Journal 119:35-40. http://dx.doi.org/10.1080/00382 $\underline{167.1981 .9630222}$

Versfeld, D. B., and B. W. van Wilgen. 1986. Impacts of woody aliens on ecosystem properties. Pages 239-246 in I. A. W. Macdonald, F. J. Kruger, and A. A. Ferrar, editors. The ecology and control of biological invasions in South Africa. Oxford University Press, Cape Town, South Africa.

Vosse, S., K. J. Esler, D. M. Richardson, and P. M. Holmes. 2008. Can riparian seed banks initiate restoration after alien plant invasion? Evidence from the Western Cape, South Africa. South African Journal of Botany 74:432-444. http://d x.doi.org/10.1016/j.sajb.2008.01.170

Walker, B. H., and W. L. Steffen. 1999. Interactive and integrated effects of global change on terrestrial ecosystems. Pages 329-375 in B. Walker, W. Steffen, J. Canadell, and J. Ingram, editors. The terrestrial biosphere and global change implications for natural and managed ecosystems. Cambridge University Press, Cambridge, UK.

Wicht, C. L. 1945. Report of the committee on the preservation of the vegetation of the South Western Cape. Special Publication of the Royal Society of South Africa, Cape Town, South Africa.

Wicht, C. L., J. C. Myburg, and P. C. Boustedt. 1969. Rainfall at Jonkershoek Forest Hydrological Research Station. Annals of the University of Stellenbosch 44 Series A(1):1-66.

Wickham, M. 2005. Letter to the editor. Cape Times, January 24, 2005.

Wilcove, D. S., D. Rothstein, J. Dubow, A. Phillips, and E. Losos. 1998. Quantifying threats to imperilled species in the United States. BioScience 48:607-615. http://dx.doi.org/10.2 $\underline{307 / 1313420}$

Yeld, J. 2004. Big green tree debate—you decide. Cape Argus, April 13, 2004.

Yeld, J. 2009. City set to review policy on pine trees. Cape Argus, January 6, 2009.

Zietsman, C. 2000. Safcol se plan oor dennebome ontketen storm. Die Burger, November 27, 2000.

Zimmermann, H. G., V. C. Moran, and J. H. Hoffmann. 2004. Biological control of invasive alien plants in South Africa, and the role of the Working for Water programme. South African Journal of Science 100:34-40. 